\title{
Starting from the End: Kant on Humanity, History and Society
}

\author{
Daryl L. Hale
}

\begin{abstract}
This paper presents Kant in a different light, as an Enlightenment thinker who is historically situated,aware of the dark pages of human history, but also hopeful about humans moving towards peace by developing dispositions of reciprocity. Since others have approached issues from the position of Head or Heart, Kant goes beyond this by noting the role of Hands in our becoming more historically astute. Toward that end, I use examples from craftsmanship to expound Kant's notion of humans as persons, not mere things. We become persons by developing a love of integrity as basis for our various activities, projects, and ends.
\end{abstract}

Index Terms-Adam ferguson, ends of reason, hidden plan of nature, Immanuel kant, persons as rational free and equal.

\section{INTRODUCTION}

What we call the beginning is often the end/ And to make an end is to make a beginning. The end is where we start from... And the end of all our exploring/ Will be to arrive where we started/ And know the place for the first time.

[T. S. Eliot, "Little Gidding", Four Quartets]

Eliot is right about the narrative character of human life. For those in the Academy, a dissertation defense closed one chapter in life, only to commence a later chapter of teaching the young and writing books. For those in practical fields, one finalizes a journeywork by becoming a master of the craft teaching apprentices the knowledge-base, subtler practices, and respect for proper tools of the trade. So Eliot is on target about the ways in which making an end is also making a beginning. And yet, his other insight is equally profound: what we call the beginning of a project is oft really the end. Had we no grand vision of an ultimate end of our activities, we hardly could be motivated even to start it. When the mastercarpenter builds a multi-leveled deck or detailed desk, s/he starts by sketching out a plan or blueprint, already visualizing the completed product. So in this respect, the end also is 'where we start from'.

\section{ENDS OF DARKNESS OR LIGHT?}

Many philosophers in recent years have expressed increasing doubts about the role of ends in human experience. They don't deny that ends drive humans to act. Rather, they worry about only one sort of reasoning that drives humans in this post-industrial age, instrumental reasoning, the kind that is concerned only with which means will be the most efficient at attaining the end(s) desired; this instrumental reasoning

Manuscript received November 30, 2015; revised March 30, 2016.

D. L. Hale is with the Philosophy and Religion Department, Western Carolina University, USA (e-mail: dhale@email.wcu.edu). then, it is argued, has led to rather inhumane modes of rationalization and behavior. Jonathan Glover in his Humanity: A Moral History of the Twentieth Century, spells out some of the dark ways in which humans have been inhumane to others merely by being more proficient at becoming masters in the 'killing fields' - the Nazi Holocaust, Stalin's pogroms, China, Cambodia, Rwanda, all of these examples of ways in which some humans failed to recognize a sense of shared humanity with others. Glover notes we need to remain aware of our dark past - war is deep in human nature -- so that we can act more humanely, that is move toward light or peace, for the future.

Glover's book starts with an epigram that informs his book on contemporary moral history from R. G. Collingwood that is telling: 'It is the chief business of twentieth-century philosophy to reckon with twentieth-century history'. And Glover's examples of the killing fields certainly detail some of the darkest moments in twentieth-century history. Yet, Glover ends his book, with some hints of light for the future (see [1]). Notwithstanding Glover's hopefulness, many postmodern philosophers have traced a lack of meaning and moral ends to the Enlightenment. They argue that with the inception of the Scientific Revolution, thinkers of the Enlightenment simply dropped out any concern for morality from their thinking, and highlighted only instrumental modes of reasoning, valuing efficient rather than final causality in science and philosophy. In thus stressing only calculative ends attained by scientific reasoning, these thinkers led us, inevitably they argue, down the dark paths and to darker minds that raised the smoke of Auschwitz ${ }^{1}$. Perhaps the path is a bit indirect and meandering, but we can see the logic, and certainly feel the fears.

Like Glover, we can recognize the dark realities of human interactions in history, but also like Eliot, we can 'arrive where we started' with some lessons learned from history. Lately, critics also worry about ways in which the Market is not so free after all, in its free-for-all, since it seems to privilege Light only for a few, promising instead Darkness for 'the Many'. So what markers might we find for guidance through the land of Light and Shadows?

\section{HISTORY FROM HEAD OR HEART?}

Most of human history is written from the perspective of the Head or the Heart. That is, it is often described from a panorama of high-minded optimism about better historical

\footnotetext{
${ }^{1}$ Possibly the most famous Enlightenment critique along these lines was that given by the Frankfurt School of Critical Theory, encapsulated in Max Horkheimer and Theodor Adorno's Dialectic of Enlightenment, first appearing in print in Amsterdam in 1947; its influence on cultural criticism has been immense.
} 
outcomes, simply by reconstructing society with the right set of institutional structures. Plato and Marx come immediately to mind as advocates of this sort of Light ${ }^{2}$. On the other hand, history also assaults us from a tragic, shadowy perspective, one immersed in a grieving pessimism about human affairs. Here, the shadow of Hobbes is a long one, cast over 'political realists' and Critical Theorists of our $\operatorname{age}^{3}$ : humanity is forever sinking into a 'new barbarism'. Yet others propose Adam Smith as a hardheaded realist about human nature when we are gut-level honest about what motivates our transactions with others, we notice a rational, though somewhat egoistic self-interest driving us ${ }^{4}$. But along with such 'realism' comes a reliance on calculative reasoning, which postmodern critics fear provides yet more grist for the mills of darkness. Still, each of these positions represent the Head outlook, either dogmatically trying to visualize a better society than our current one, or else smugly criticizing all such endeavors as little more than high-minded naivete. With such stark, oppositional attitudes, no wonder we find ourselves in such a polarized present.

Those who have proposed Heart strategies, while correct in discerning other motives than those of the Head, still have been unconvincing of the role of passions as a singular causal analysis of human and historical complexities. Perhaps here, the ancient Greek philosopher Epicurus counts, as one who proposed that a cheerful Heart could empower one to forego superfluous pleasures'; or maybe that 'subtle Diogenes' Rousseau resonates in his advocacy for return to a natural goodness of a simpler lifestyle - driven by a good Heart and will -- over the cultural excesses one finds in modern societies ${ }^{6}$. We find vestiges of these earlier thoughts in modern movements for naturalist or moral religions as well

\footnotetext{
${ }^{2}$ See Plato, Republic, for his reconstruction of society by starting all over again, beginning the ways children are educated - new edifying myths, new literature and poetry, moderate forms of music, harmonic bodily training, new political structures under governance of a philosopher-king. For Karl Marx, see his Manifesto of the Communist Party for his outline of how to correct abuses of modern society suffered under capitalism; also Engels' "Socialism: Utopian and Scientific" tackles the problem of over-relying on technical or instrumental reason for measuring all things in the bureaucratic state - it leaves out the political commitment to equality.

${ }^{3}$ See Thomas Hobbes, Leviathan, especially the Introduction and Chapter XIII, on the natural condition of humanity: in the state of nature, humans live in continual fear and danger of violent death; the life of humans is 'solitary, poor, nasty, brutish, and short'.

${ }^{4}$ See Adam Smith, The Wealth of Nations (London: 1776). Famously, Smith there claimed that it was not a sense of benevolence of the butcher, brewer, or baker that we expect our dinner, but from them looking to their own interest. See Book One, Chapter II. Most libertarian economists seem only familiar with this passage, and overlook his earlier book, A Theory of Moral Sentiments (1759), in which he argued also for the natural human disposition of sympathy that drives us to help others. This point seems conveniently forgotten by neo-conservative writers.

${ }^{5}$ This aspect of Epicurus gets overlooked by many. Though he stressed pleasure as the greatest good, Epicurus also claimed that friendship and a community of friends empowered one to attain the greatest pleasures. See Cicero, On Goals, I.65-70; Epicurus, Principal Doctrines, 271; also other Epicurean teachings stressing the values of friendship and the happy heart are found in Brad Inwood and L. P. Gerson, The Epicurus Reader (Indianapolis: Hackett, 1994), 'Ancient Collections of Maxims', 39, 41, 52, 66, 78.

${ }^{6}$ Rousseau's defense of the life of natural, or Spartan, simplicity was given in his Discourse on the Sciences and Arts of 1750; he continued this line of argument, and extended it to argue against Hobbes that there was a natural goodness of humans uncorrupted by the vices of civilization in his Discourse on the Origin of Inequality of 1754; had we noticed that, Rousseau argues, we would also notice, contrary to Hobbes, a natural human disposition of pity that moves us to act on behalf of those we see suffering.
}

as in 'back to earth' local farmers' market cooperatives and organic farms. While it is undoubtedly true that the 'spasms of the Heart' - its passions of love and hate, desires for honor and defeat - motivate many human actions, focusing only on human affective cognition oversimplifies the plurality of human motives, historical interactions, and the diversity of lives we lead. Even if the Heart demands its due from us, it need not bid abject subservience; sometimes we rise to the occasion and practice self-mastery, even if not as often as we hope.

Accordingly, the end of all these explorations, from perspectives of both Head and Heart, seems to promise little for Eliot's hope of our end of 'arrival and first-time knowing' of earlier histories of our lives and cultures. Are we then at the end of our strivings to attain wisdom from humanity, history, and society? Perhaps not. To return to my opening metaphor of the craftsman, we might think about a third possibility. The mastercraftsman approaches his/her projects by three main strategies. First, once informed of what the end is - building a desk, multifunctional deck, or child's playhouse $-\mathrm{s} /$ he begins by outlining a plan(s) or blueprint(s) of that end. This outlined plan is clearly a use of the Head. Second, one also incorporates into one's revisions (of original plan) the needs of the customer for whom one is building the desired object; and this always includes the needs of the Heart, such as what end(s) that completed object will accomplish: a place to read or study, a deck with hot tub to soothe a senior's pains, or perhaps a place of camaraderie and play for the young. Notice also that the genuine craftsperson interacts regularly with the customer to assure the finished product is such that it maximally actualizes the end envisioned - to empower the learner with more options; to help the injured to recover; to embrace the child's playful imagination \& community sensibility. Third, the craftsman uses his/her seasoned hands to construct - knowingly, passionately, and durably - an end that meets a variety of needs, goals, and interests. So, the third possibility that emerges is engaging the thoughts of the Head, and the passions of the Heart, in the wise constructions of the Hands. Could it be that a grieving optimism - full awareness of the dark aspects of human history (grieving), but balanced with hope on basis of our use of reason that adapts to human contingencies -- may help us uncover Light from the Darkness yet.

How can we hope to find such help from the Hands with cultural voices calling for commitments either to Head or Heart? Are there any philosophical perspectives that incorporate all three of these avenues of learning? What help from history?

\section{Is REASON A SLAVE OF PASSIONS, No ENDS?}

In recent moral philosophy, it has become something of a given to assume that no philosopher of the Enlightenment is open to anything other than instrumental, means-end, forms of reasoning. If true, this is devastating, since it seems we have little freedom in the world in which we live; our lives are then so dominated by some sort of utilitarian sort of calculus that condemns us, almost Sisyphus-like, to scream out for more pay, or leisure time, since any hopes for real freedoms in our lives are crushed by the wealthy and power 
elites. One philosophical tradition that treats reason as merely instrumental is that of David Hume, who asserted that human reason is little more than a slave to our passions ${ }^{7}$. In our sense, this means that Hume is a strong advocate for the Heart perspective.

Alasdair MacIntyre has given one of the strongest critiques of 'the Enlightenment project'. His After Virtue presented a powerful defense of a restored Aristotelian- Thomistic virtue ethic, a moral philosophy he finds lacking in modern moral theory, especially in utilitarianism and Kantianism. MacIntyre argues that we have followed rule-directed modern moral philosophies like these that correlate with the efficient causality of modern science, and in so doing we have lost our way in the modern age by abandoning the telic reason (from telos, Aristotle's word for 'end, goal, purpose') inherent in ancient and medieval thought. Here is his argument:

1) One primary commitment of Enlightenment thinkers, like Descartes \& Spinoza, was to the superiority and success of the natural sciences and mathematics; one method that promised progress was to eliminate the need for final causes from modern science; efficient causality was deemed sufficient for a scientific investigation of nature.

2) And in moral philosophy, Hume showed the ultimate impoverishment of Enlightened thought - reason is 'ever slave to the passions'; moral judgments are merely expressions of feeling, of emotive states of mind; it is the passions, not reason, that move us to action. And in economic thought, such as that of Adam Smith, we get no further - when teleology is abandoned, one is left only with a bland Deist Stoicism, that substitutes Nature for God; the virtues of prudence, justice, and benevolence are now equated with rule-following, with little idea of how to follow those rules; and individualist self-interest becomes the dominant motif in the modernist age.

3) Thus, we should abandon the impoverished Enlightenment view of humans \& Nature as merely governed by instrumental rationality, moral emotivism, economic self-interest, and ontological individualism, instead restoring an Aristotelian-Thomistic teleological virtue ethic that recognizes the true end of humans (embedded in telic reason, religious tradition, and a unified moral narrative of one's life) [2].

One can hardly overvalue MacIntyre's deep contributions to moral philosophy. He has taught all of us - Kantians, utilitarians, libertarians, liberals, and Marxists - how to reconsider our positions in light of a powerful attack by and defense of a neo- Aristotelian virtue ethic, the importance of reason in moral traditions, and the centrality of narrative in thinking about our lives and actions. Further, he has reinstilled something sorely needed in contemporary philosophy - a deep awareness that moral philosophy has a history; too many journal jousts arguing verses in Hume or Heidegger lost sight of that.

\footnotetext{
7 "Reason is, and ought only to be the slave of the passions, and can never pretend to any other office than to serve and obey them." David Hume, A Treatise of Human Nature, Bk. II, Pt. III, Section III (Oxford: Clarendon Press, 1980), 415.
}

Still, while this argument is impressive, it falls short in some respects. For one thing, there is no single Enlightenment, but several - minimally French, Prussian, Scottish, and American - versions, each with tellingly different features. Consider the atheist tendencies of French versus critical theist tendencies of Prussian Enlightenments for one example. Historian Jonathan Israel pointed out the profound differences between radical and moderate versions of Enlightenment [3], [4]. Second, while many treat Adam Smith's position as reducible to an individualistic, instrumental view of rational self-interest, that hardly does justice to Smith's extended argument for social justice issues, as Amartya Sen and Martha Nussbaum have noted in their works (see Sen's introduction to the 2009 Penguin reissue of Smith's 1759 The Theory of Moral Sentiments, see [5], and Nussbaum's Creating Capabilities). Following received wisdom, Smith did see restrictions on trade and on free movement of labor as impediments, but against received opinion, he also urged actions against any practices that inhibited development of human capacities, like coercive apprenticeships, powerful monopolies, and the slave trade, all invasions of human freedom. As Nussbaum points out, Smith rejected the Stoic doctrine of invulnerability. Accordingly, he argued for government intervention for those programs that would insure a fuller development of human capabilities, such as free compulsory public education and wage regulations that favored the workingmen. So, the received view of Smith as driven only by narrowly-conceived rational self-interest must be severely revised $[6]^{8}$. Third, it is simply not true that no one after Hume offers any arguments on behalf of human ends that transcend narrow instrumental uses of reason. At least three thinkers replied to Hume Thomas Reid and Adam Ferguson in Scotland and Immanuel Kant in Germany-by offering arguments to show that humans do reason about their true ends; those true ends are the moral vocations that all humans, even the most ordinary thinkers, pursue, and they transcend or precede our desires for material goods, products, and services.

\section{KANT: Humans as PERSONS, LABOR AS Dignity, ETHICS AS HUMANIZED}

Kant speaks of human beings as persons, those beings who, due to their own natural freedom, can construct moral ends of their own over against the ends of inclination. Now, while it is true that I can be constrained by others to perform actions that are directed as means to their ends, still due to my freedom, I can never be constrained by others to make their ends mine, since only I myself can truly make something my end (self-legislative reason). Nonetheless, though I cannot make others' ends mine, I can make my ends harmonious with those of others. The mastercraftsman has invested time, talents, and energy developing some excellences, and so has one end of being paid a reasonable wage for his work displaying such craft-knowledge. Yet this does not preclude his also adopting the ends of his employer in performing his

\footnotetext{
${ }^{8}$ Nussbaum argues that Smith is not a libertarian, but his Stoicism is infused with an Aristotelian concern for family, friends and the material conditions that contribute to human flourishing.
} 
tasks. Perhaps the customer wants a deck built that meets ends of comfort, vista access, and safety. Accordingly, the crafting person freely chooses those means that both are efficient yet also meet both the customer's ends and his/her own ends of the craft - the plans of the Head, needs of the heart, and dexterities of the Hands. Of course, one could cut corners, use shoddy materials, or invest less labor in the task at hand, thus abandoning concerns for safety, durability, and a sense of beauty. But one would thereby have abandoned one's crafting personhood, since being responsible implies that one is accountable for the proper use of one's reasonable free choices as a craftsperson.

Contrary to academic and popular assumption, Kantian persons are not isolated, self-regarding individuals. In The Metaphysics of Morals, and in his essays on History, Kant offered a cumulative argument for his personalist moral philosophy ${ }^{9}$. Since this was his last major work in moral philosophy, and we know he had been teaching his students Smith, Hume, and Rousseau in his Lectures on Ethics, we can regard this as a cumulative argument from the Enlightenment on behalf of a telic or moral end-directed use of reason.

1) A person is an individual with basic freedom of choice, accountable for one's actions, who sets one's own ends, and exacts respect from, while affording equal respect to, all other rational beings. Moral personality then is simply the freedom of a rational being under moral laws.

2) In this mutual freedom, responsibility, and equality is found human dignity.

3) Hence, a person is subject to no other laws than those one gives to oneself, either alone or at least along with others. This self-determinative aspect of humans constitutes Kant's Copernican revolution in moral philosophy. However, a human as a person, using one's ordinary practical reason, is exalted above any price; for as a noumenal being, $\mathrm{s} / \mathrm{he}$ is not merely a means to the ends of others, or even to one's own ends, but is an end in oneself, thus possessing a dignity by which s/he exacts respect from, and attains equality with, all other rational beings in the world. [MM 6:434-5]

4) Those beings lacking freedom, to which nothing can be imputed, are things. So as not to make oneself a mere plaything of our mere inclinations, and hence a thing, persons employ a basic principle of their character, the virtue of a love of integrity or equity [honestas interna]. Hence, the person of integrity values and practices truthfulness, open-handedness, and humility. But, note

\footnotetext{
${ }^{9}$ I have teased out this argument from several works in which Kant gives these premises. First, his essay "Idea for a Universal History from a Cosmopolitan Perspective" (1784) and "Conjectures on the Origins of Human History" (1786) give his most complete view on how humans slowly acquired reason, amidst many historical difficulties, and how labor and the use of our hands, via our applications of practical reason, gave us a certain dignity that other animals did not attain. Both of these essays are found in $\mathrm{H}$. B. Nisbet and Hans Reiss, Kant: Political Writings (New York: Cambridge University Press, $2^{\text {nd }}$ ed. 1991). Kant's mature moral philosophy is found in his last work on that topic, The Metaphysics of Morals of 1797; his Lectures on Ethics are compilations of student notes taken in the years 1762-4 (Herder), 1775-84 (Collins), a course given in winter 1785 (Mrongovius), and a course given in 1793-4 (Vigilantius). See Peter Heath and J. B. Schneewind, Immanuel Kant: Lectures on Ethics (Cambridge, UK: Cambridge University Press, 1997), Introduction by Schneewind.
}

closely: even things have a certain standing. Humans should respect their animal as well as moral nature; this means one has a duty to one's disposition of sensibility. This also implies that violent and cruel treatment of animals is disallowed, since it dulls one's empathy. One should show gratitude for the long service of an old horse or dog, just as if they were members of the household [MM 6:443].

How can Kant justify this assumption that humans desire to transcend their natural inclinations? Are not humans naturally inclined to seek their own interests? Does not a realist view of history surmise no grand rational plan guiding the senseless acts of humans?

5) Kant surmises: perhaps there is a hidden plan of Nature. Unbeknownst to us, there may emerge

a spontaneous, unplanned order due to the cumulative growth of many human interactions with Nature. Consider how improvements emerge over time in human history. So reason takes time to develop, but it moves us beyond a mere reliance on animal instincts. This spontaneous order thesis was maintained also by the Scottish moral philosopher Adam Ferguson in his Essay on the History of Civil Society (1767). ${ }^{10}$

6) Kant continues: Nature was frugal in providing humans with aids of animal survival - we do not have claws of a lion or teeth of a dog; instead, we merely have hands: by these, we can labor to nourish, clothe, and protect ourselves. This means we oft undergo a 'whole host of hardships' in providing for self \& family, but Labor thereby attains a sort of dignity, since 'restless Reason' presses us thereby to 'pursue distant ends in accordance with our vocation' [UNH, Prop. 2-3]. Accordingly, Nature did not intend happiness per se as our end, but for us to become worthy of flourishing. Kant then gives a defense of the dignity of human labor, anticipating Marx's later points about humans as tool-making animals and the inherent worth of the ordinary working person.

7) In Nature as an interlocking system, a human being as a phenomenon is a being merely of slight importance, sharing with other animals merely an ordinary value [pretium vulgare]. Still, in possessing understanding, a human has more than other animals in being able to set for oneself ends; but even this is only an extrinsic value for one's usefulness [pretium usus], whereby one human - the craftsman -- has higher value than another, and accordingly, some will have more preeminent value than others.

8) Nature has a special means for awakening humans to develop all our predispositions - we are naturally unsociably social. We have both a propensity to isolate ourselves from others, and also a need for social interaction. Through this very resistance - we are driven by ambition, competition \& greed to obtain a

\footnotetext{
${ }^{10}$ See Adam Ferguson, Essay on the History of Civil Society, published in 1767. In Kant's Lectures on Ethics, we find Kant displaying to his students a deep awareness of the moral insights of the Scottish school of moral philosophy - Smith and Ferguson -- especially their claims that humans have a natural tendency to show concern for and actions to alleviate the suffering of their fellow humans.
} 
recognition from our fellows, whom we 'cannot stand but also cannot leave alone'. But 'thanks be to Nature for this competitive vanity, even the desire to dominate' since without these traits, our more excellent predispositions, like a concern for humanity would 'eternally slumber undeveloped' (UNH, Prop. 4).

9) As a person, it is one's duty to make oneself more perfect (complete) than Nature has made one in one's animal nature. This means we need to develop all our talents, to increase our moral perfection, to be actively benevolent, thus becoming worthy of our humanity, recognizing our inadequacies. We have 'an imperfect duty to be perfect' [MM 6:447].

10) Accordingly, humans as persons ought to use one's moral perfections in social intercourse, seeing one's moral circle as all-inclusive, among whom one cultivates a disposition of reciprocity - agreeableness, tolerance, mutual love and respect.

\section{CONCLUSION}

In conclusion: Kant's persons are end-directed rational and social beings by their dialectically intertwined dual-aspect - animal and social , sensibility cum understanding -- natures. We are driven by Nature to develop both our more complete individual and social natures, improving though perhaps never completing our drives toward tolerance and peace. Finally, when we cultivate a disposition of reciprocity, we complete Eliot's hope of arriving where we started, and knowing not merely the place, but self, others, and world for the first time. Those who refuse even to try to do so seal their own cycles of defeat, depression, and violence. It is our end to make a beginning, even if Justice and Equity are still realizable hopes in the future. As Glover reminded us, we have seen enough billowing smoke clouds from the furnaces for one century. A more humanized ethic keeps the past alive in the present, but also presses us onward to create a world in which there is less suffering and more imperfectly perfect personality.

\section{REFERENCES}

[1] J. Glover, Humanity: A Moral History of the 20th Century, 2nd ed. New Haven: Yale University Press, 2012.

[2] A. MacIntyre, After Virtue: A Study in Moral Theory, Notre Dame: University of Notre Dame Press, 1981.

[3] J. Israel, Enlightenment Contested: Philosophy, Modernity, and the Emancipation of Man 1670-1752, New York: Oxford University Press, 2006.

[4] J. Israel, Democratic Enlightenment: Philosophy, Revolution, and Human Rights 1750-1790, New York: Oxford University Press, 2011.

[5] A. Sen, "Introduction," in The Theory of Moral Sentiments, A. Smith, ed. New York: Penguin Press, 2009.

[6] M. Nussbaum, Creating Capabilities: The Human Development Approach, Boston: Belknap Press, 2011, pp. 132-138.

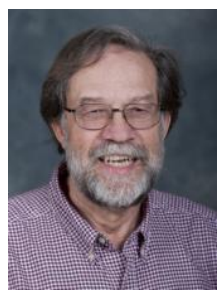

Daryl L. Hale is an associate professor in the Department of Philosophy \& Religion at Western Carolina University. Regular courses taught include kant \& early modern philosophy, classical \& late antiquity, medieval \& reformed thought, history of early christianity, global justice, and religion \& science. His manuscript Stoics and Epicureans (read by Lynn Redgrave) led to discoveries of Stoic and Epicurean influences on early modern thinkers, an article on Thomas Jefferson's philosophy, and upcoming manuscript on Jefferson's neo-Epicureanism. He also published an article on the neo-Platonic philosopher, Proclus. In the fall of 2014, he spent a sabbatical in Germany, completing a manuscript in December 2015, Honoring the Rabble: Kant's Copernican Vision for Reason \& Nature (under consideration at university presses).

His education includes a BA in philosophy from Calvin College (MI), where he studied Kant's Critique of Pure Reason with Nick Wolterstorff, and his $\mathrm{Ph} . \mathrm{D}$ in philosophy was earned in 1991 on Kant under the guidance of John Lachs at Vanderbilt University, Nashville TN in the USA.

Daryl practices a second, largely summer, profession as a mastercraftsman in carpentry, having studied with a master timberframer, learned the rules of the craft, and displaying paradigms of the craft at http://www.durabletimbers.com/ . For more on how philosophers master the craft of argument construction, see Plato's Gorgias and Alasdair MacIntyre's Three Rival Versions of Moral Enquiry (Gifford Lectures 1987-8). 